Webster, E

One more tune! The encore ritual in live music events.

Popular Music and Society,2012, 35 (1). pp. 93-111.

10.1080/03007766.2010.538241

This version is available: http://radar.brookes.ac.uk/radar/items/b68d4819-7fb6-de27-f21d-d1b1d1135c03/1/

Available on RADAR: October 2013

Copyright (C) and Moral Rights are retained by the author(s) and/ or other copyright owners. A copy can be downloaded for personal non-commercial research or study, without prior permission or charge. This item cannot be reproduced or quoted extensively from without first obtaining permission in writing from the copyright holder(s). The content must not be changed in any way or sold commercially in any format or medium without the formal permission of the copyright holders.

This document is the author's accepted manuscript of the journal article, published online in Popular Music and Society, 22 Feb. 2012, and copyright Taylor \& Francis. Some differences between the published version and this version may remain and you are advised to consult the published version if you wish to cite from it. 
"One more tune!" The encore ritual in live music events

\section{Emma Webster}

The encore ritual at live music events is a ubiquitous yet under-researched phenomenon. Drawing on ethnographic research carried out in Glasgow, Sheffield and Bristol, this paper deconstructs the encore ritual as it is enacted by performer and audience, and highlights the covert yet vital complicity of the promoter/venue. It argues that while the encore began as a spontaneous display of audience enthusiasm, it has now become an expected and ritualized part

of a live music performance. The paper illustrates how encores now fulfill a variety of functions, including indicating temporality, allowing artists to thank their audiences, and allowing the audience to feel some semblance of empowerment within the event.

Please note that this article was originally published as "One More Tune!" The Encore Ritual in Live Music Events by Emma Webster in Popular Music and Society, Vol. 35, Issue 1, 2012. Permalink on Taylor and Francis website: $\underline{\text { http://dx.doi.org/10.1080/03007766.2010.538241 }}$

\section{INTRODUCTION}

A BBC Radio 4 documentary, Encore!, began with Elbow front-man, Guy Garvey, describing his band's gig experience: "We've finished our set. The audience wants more. Will we go back on? Of course. The encore, instead of being a surprise ending, has become a ritual." What began in the eighteenth-century as a spontaneous display of audience enthusiasm - encore is literally French for "again" - has now become standard. This paper will argue that the encore is now an expected and ritualized part of some performances which fulfills a variety of important functions. Live music has always been an important consideration for popular music and its related 
industries, and yet it has been surprisingly neglected in research. The economic importance of live music is one area to be researched, ${ }^{1}$ but there are many others in this rich field that may be considered and that have not yet been fully explored. Encore rituals are particularly interesting because they highlight some of the complex relationships and structures at work in a live music event. These include the increasing regulation and mechanization of the live music industry, the complex relationships between audience and performer, the vital yet covert role of the venue/promoter, and the temporality of the live music event as a whole. The somewhat contradictory and peculiar nature of this ritual, however, may be summarized thus: live music audiences crave authenticity from artists and therefore an encore only makes sense if it is enacted and perceived as being spontaneous. Nevertheless, the fact remains that encores are (usually) rehearsed moments which audiences now expect.

This paper will deconstruct the encore ritual as it is enacted by the artist and audience, and examine how the promoter and/or venue understands it, and offer some thoughts as to its meaning and why it remains a persistent part of the live music event. ${ }^{2}$ Encore rituals are usually found at what Thomas Turino defines as presentational performances, defined as "situations where one group of people, the artists, prepare and provide music for another group, the audience, who do not participate in making the music or dancing" (26), rather than participatory performances, referred to as "a special type of artistic practice in which there are no artistaudience distinctions, only participants and potential participants performing different roles, and the primary goal is to involve the maximum number of people in some performance role" (ibid.). This paper will therefore focus on the former, because the encore ritual, as will be seen, forms an important function for audiences within a presentational performance that is unnecessary within a more participatory one. The paper draws on participant observation at venues in Glasgow, 
Sheffield and Bristol, interviews with relevant venue personnel and audience members, and many years of personal participant spectatorship at live music events within the UK; the paper consequently focuses on UK-based events for the most part.

The use of music in ritual contexts has long been recognized and discussed by ethnomusicologists and anthropologists alike (for example, Merriam; Nettl; Blacking). Christopher Small and Wendy Fonarow assess music's role in Western music events, and deconstruct the rituals surrounding symphony concerts and indie gigs respectively. Neither Small or Fonarow dwells on the ritual within the ritual that is the encore, however, and, other than a few brief mentions in the literature (for example, Fairley and Pitts), the encore ritual is currently a fairly ubiquitous yet under-researched feature of the musical event, a gap which this paper aims to fill. When the encore is discussed in the literature it is often done in a dismissive manner, such as in Eric Blom's 1934 essay on listening and performing, in which he describes the "curse of the encore" as a "ridiculous convention" to which conforming artists should be regarded with "suspicion" (671). Encore rituals are also derided both by some members of the audience themselves (see Pitts 104) or in the popular press. Words such as "insincere," "pervasive" (Barber); "clichéd," “ego-wank" (Botten); "boring” and "predictable” (Simpson), may all be found in articles criticizing the encore ritual. Indeed, the predictability and speciousness of the encore ritual is one of the reasons cited by Wendy Fonarow for older indie fans to ultimately leave the indie world behind (201-202).

A comparable (but markedly different) event in theatre is the curtain call, ${ }^{3}$ and a similar dearth of research on the topic is apparent in the field of theatre studies. Baz Kershaw offers an interesting article on patterns of participation in twentieth-century theatre, in which he suggests 
that British theatre audiences since 1945 have gradually become "disempowered," "dispossessed," and "commodified" as they have mutated from patrons to clients, and then from clients to customers, and that the use of applause and the curtain call is now "the major expression of audience as community in the late twentieth century" (141). Martin Revermann draws on Kershaw's work to offer a semiotic analysis of curtain calls, describing them as "liminal mini-dramas" which contain a reversal of power from actors to audience, and which are a "mutually communicative and evaluative act ... [for] self assertion and mutual (re)energizing as well as of reflection on the part of both the actors and the audience on themselves as well as on the relationship between each other" (194). Erving Goffman, in his work on frame analysis, would perhaps have viewed the encore ritual as being at the "interface of spectacle and game" and an opportunity for the artist to "down-gear" (175-6). Simon Frith theorizes the encore ritual a little more straightforwardly, however, to write that "an encore can be evaluated from three perspectives: it is an ending ritual; it draws attention to the relationship between performer and audience; and it suggests a difference between performance as rehearsed and performance as spontaneous" (Frith, "Re: Encore rituals"); this framework will be returned to later in the paper to explore the functions and meanings of the encore ritual.

\section{THE ENCORE: A BRIEF HISTORY}

The first task is to examine the origins of the ritual before exploring it in more depth, to show how the encore has morphed from being a spontaneous action to a commercialized practice, to what is nowadays a ritualized response to a performance. The use of this French word in England by audiences to encourage the artist to perform a song or piece again - even during an opera or recital - dates back to at least 1712 , at a time where the use of the word had a fashionable status and the occurrence was spontaneous (Walls). By the nineteenth-century, virtuoso musicians such 
as Liszt saw the encore as an opportunity to try out something new on an audience, or a chance to show off (Encore!). Professional claquers, or more specifically bisseurs, ${ }^{4}$ were employed in Paris in the 1820 s to shout for an encore, and the practice continued in London in the midnineteenth century and in the early twentieth-century at New York's Metropolitan Opera House (Scholes). Encores during the performance were banned, however, by La Scala opera house in Milan in 1933 after the conductor Toscanini became irritated by the interruption to the flow of the opera (Rome), ${ }^{5}$ thus disempowering the audience by forcibly moving audience participation to the end of the opera.

Today, an encore will usually only be performed at the apparent end of a performance, and, in the classical world at least, often only to very enthusiastic applause and/or a standing ovation. ${ }^{6}$ Due to their ephemeral nature and previous lack of research, it is not clear when the encore tradition crossed over into popular music and jazz and became a standard part of a set. ${ }^{7}$ If one abides by Richard Peterson's argument for 1955 as the year for the advent of rock music, the fact that Elvis Presley was said to be called back for "encore after encore" in May 1955 ("Elvis Presley 1953-55") would suggest that the encore was present at the start of the rock era, although interestingly, by 1956, Colonel Tom Parker had realized that by not doing an encore, the audience were left wanting more (Aston). The Beatles famously never played encores after they had "made it," except for one rare occasion in Paris in 1965, when Paul (presumably at the behest of the organizers) introduced the regular closing number, "Long Tall Sally," as an encore after The Beatles had left the stage for a brief moment. The Monterey Pop Festival in 1967 certainly contained encores (Lydon), and by 1978, David Bowie was said to have chosen to "conform to the encore ritual" (Sutcliffe, "David Bowie: City Hall, Newcastle"). ${ }^{8}$ Now in 2010 it is argued that the encore ritual has become both an expected and a significant part of certain 
music based events ${ }^{9}$ as can be shown by examining its many functions and meanings within the four types of encore ritual, as follows.

\section{EXPLORING THE “NORMAL” ENCORE RITUAL}

The encore ritual breaks down into four types: normal, deconstructed, disturbed, and omitted. A "normal" encore ritual would be when the artist announces that they will play a final song ${ }^{10}$ (or the final piece is indicated in the program), and then performs this "final" song or piece. At the end of the song and the false end of the set, the artist will usually step away from the microphone (if used), remove or step away from any instruments, and thank the audience - "Thank you very much, g'night!" - who will often be applauding and vocalizing (whooping and cheering) by this point. The audience will often begin to stamp their feet - either while standing or seated - in an arrhythmical manner, ${ }^{11}$ which may crescendo or accelerate as the artist leaves the stage, and the houselights will remain down. When the artist has left the stage and can no longer be seen, the audience's arrhythmic stamping or clapping may segue into a unified rhythmic beat, sometimes accompanied by chanting the artist's name in unison, or chanting "More!," "Encore!" or "One more tune!" After a break of around one or two minutes, the artist will reappear, pick up their instrument(s) again and perform the actual final song(s), then leave the stage for good. After this occurs, the houselights will come back on and background music (if used) will start up again, signaling the end of the event to the audience, who will then usually start to leave the venue.

\section{Status}

A number of points may be made about this "normal" encore ritual, the first being that encores are usually limited to headliners rather than local support artists, and therefore act as a means of conferring status and hierarchy on the artist who is allowed to perform one. This acts both as a 
signal to the audience that they are the most "important" act of the night, and also to send the message to other actors within the event - such as the support acts and the music industries which may in turn affect the economic, social and cultural capital of an artist. At modern-day festivals such as Glastonbury, for example, only the headline artists - the final act on a stage are granted an encore, where an artist must be agreed and noted as the headliner to receive the accolade. As one festival production manager explains, "If it's your own show, then no problem, but if you attempt to do it at [major UK festival], and are third from last on, I will be pulling your stage power, and putting you back in your box!" (anonymized). As Sam Francis - production assistant at King Tut's Wah Wah Hut in Glasgow - further illustrates, support acts and those further down a festival bill are:-

\footnotetext{
Not there to headline the show - they're there to support. . . I guess a lot of grass roots bands don't see it as [such] a necessity to do an encore than it would be to an artist that's sold millions or sold a good number of units to a point where people want to hear more of their music.... I guess that's just how it works; there's no-one that says, you know, 'You can't do it' . . It's just not the 'done thing'. I think it's like an unwritten thing, you know what I mean? You just don't do that (Francis, emphasis in original).
}

The lack of an encore ritual for support acts or those further down the bill, however, can make the ending ritual problematic as their last number may feel anti-climactic. This may be further heightened by the need to prepare the stage for the headliner, often carried out by venue crew and even by the support act themselves. For example, at King Tut's, the support acts would often leave the stage to applause (which would quickly fade), ${ }^{12}$ usually to wait in the liminal space at the stage-left side of the stage, only to then reappear back on stage to tidy away their instruments and equipment in preparation for the headline act. ${ }^{13}$ 
Status can also be seen in the length of time an artist will leave the stage before reappearing. At King Tut's, the average length of time was two minutes. In contrast, at a Police concert at New York's Madison Square Gardens in 2008, Sting left the stage long enough to receive a shave and a manicure backstage, all of which was streamed live on video to the screaming crowd, before he reappeared for the encore (Chinen). The total length and number of encores are also partly dependent on status and musical genre: Bruce Springsteen, for example, often plays encores lasting thirty minutes, while jazz musicians may play three or four encores (Rodger). The length of time for an encore may also be partly due to time restrictions, as will be discussed later in the paper.

\section{Ending Ritual}

The second point to be made is that the encore is part of the ending ritual. All performances have to end, and endings have to be marked somehow; this varies from genre to genre, as reflected in the signals used between musicians and audiences to signify the end of the performance (the removal of bows from strings, a band jumping in unison on the final chord, etc.). An encore then, when it happens, acts as a means of highlighting the temporality of the musical event and indicating that it is close to finishing. As Anthony Jackson writes in his work on sound and ritual, "If rites have a marked off time, it means that they are to be specially placed in chronological time and hence there must be indicators to denote the beginning and the end of the rite besides the sequential order of events" (296), hence the artist's use of the false ending "This is our last song" - just before the encore. One infamous example of an ending ritual is that of the James Brown show in which Brown would be helped off the stage, supposedly too 
exhausted to continue, after which the MC encouraged the audience to demand more so vociferously that he would have to return, which he duly did, miraculously rejuvenated.

More than once during my time at King Tut's, the behavior of the audience became more energized and less self-conscious at the (false) announcement of the final song, as if the audience had reserved their energy until the end so as not to exhaust themselves too early on. The encore is often also a place for increased verbal interaction between the artist and the audience. For example, at a Ray Davies gig I attended at the Glasgow Royal Concert Hall, during the first break after the false ending, some in the audience began to shout "Sing "Lola"!" with some even going so far as to start their own rendition of the song before Davies returned to the stage. What would have earlier been an unwelcome interruption, the audience's shouting out of requests instead becomes an invited and expected part of the encore ritual. Each encore therefore segments and marks out time. As Martin Cloonan notes "In many ways the encore marks the end of losing a sense of time when at a music event; once the encore is over the audience know that the event is nearly over and the audience must return to 'real life,' hence the heightened excitement" (Cloonan). It is argued here that the encore now forms the ending ritual for some performances, as audiences have come to expect it as the ending ritual.

\section{Spontaneity and Rehearsal}

The third point to be made is that the choice of song for the encore is of interest as this may affect whether an encore feels spontaneous or rehearsed. Returning to Frith's framework, the encore ritual suggests a difference between a rehearsed and a (seemingly) spontaneous performance, and because an encore is supposed to be unplanned, there needs to be an indicated difference between the performing conventions of the show and the encore. This may mean that, 
for the encore, an orchestral or classical soloist may perform without a score, as to have a score on the music stand may be construed as somewhat presumptuous and rehearsed. Similarly, for popular music, jazz or folk, the equivalent may be a singer songwriter who begins the encore by saying, "I haven't practiced this so I may forget the words ..." Artists may choose to take requests for the encore, which may be perhaps perceived as a more spontaneous act, or fulfilling Goffman's concept of "down-gearing." One example of this is Bruce Springsteen, who used to play rock and roll standards for his encores as if repositioning himself as a fan.

Artists may also choose to play a cover version of another artist's song, again as a result of "down-gearing," or as homage to other artists. Taking requests ensures some feeling of spontaneity; performing a cover perhaps less so. Covers do not have to feel rehearsed though, as the following example illustrates. The final song of the encore at Glasgow-based band Zoey Van Goey's album launch gig was a rendition of Velvet Underground's "I'm Sticking with You." During the final section of the song, the multi-membered support act, Second Hand Marching Band (SHMB), slowly filed on to the stage from the dressing room, until there were more than twenty people crammed in front, behind, and to the side of the main act. As Matt Brennan from Zoey Van Goey recalls:-

On the afternoon of the gig when most of [Second Hand Marching Band] were hanging around during sound check, we asked them if they wanted to play, told them the (three) chords and they were up for it. However, we didn't have a full (or possibly any) actual rehearsal of the song and I distinctly remember being shocked hearing the parts that SHMB invented on the spot during the encore, thinking 'This sounds way way better than I expected!' (Brennan).

While this shows that the encore had to be rehearsed (to a point), and that such a complex feat would have been difficult to do spontaneously, ${ }^{14}$ the gradual appearance of SHMB during the 
song appeared to be spontaneous, as if the Zoeys had, Pied Piper-like, lured them on stage. The addition of guest artists in this way is another means for an artist to "add value" to the encore. One lauded example is that of a War Child benefit gig featuring Coldplay and The Killers at the $\mathrm{O}_{2}$ Shepherds Bush Empire in 2009. Both bands curtailed their main sets so as to beat the venue's curfew in order to allow Chris Martin to perform an encore with Take That's Gary Barlow, then The Killers and U2's Bono, in a (supposedly) briefly rehearsed rendition of The Killers' “All These Things That I've Done.” The U2 singer's knowledge of the lyrics was described as "shaky" but his uncertainty consequently rendered the encore as more spontaneous ("Killers, Coldplay, U2, Take That Team-up for Post BRITs gig"). Encores, of course, may also be crowd-pleasing favorite songs, as discussed in more depth below, or the choice of song may have become ritualized itself, such as with Queen's performance of "We Are the Champions" and "We Will Rock You" for their encore, or Oasis' cover of The Beatles" "I Am the Walrus."

While the encore is meant to feel unrehearsed, it is argued here that many encores have lost any semblance of spontaneity, as audiences now expect them at the end of the performance. At the majority of music events attended during the author's research period, there has often been no attempt to hide the pre-planned nature of the encore, and this is highlighted by the following two examples. Firstly, at the Glasgow Royal Concert Hall, the set times are displayed on plasma screens in the foyer, and the scheduled end of the show is sometimes twenty minutes after the artist announces the "final song" before the encore. The second example would be the highly choreographed encore at a "Here Come the Girls" concert at the same venue, where the three performers (Lulu, Chaka Khan, and Anastacia) said their "final" farewells and left the stage, leaving the audience in darkness, screaming for more. The trio then reappeared for the actual encore two minutes later, which featured a choreographed routine by the dance troupe, 
synchronized video footage on the screens surrounding the stage, a seamless backing track and pre-rehearsed harmonies by the three singers, a costume change, and Chaka Khan being wheeled on stage on a previously unseen chaise longue. Such obviously pre-rehearsed elements effectively negate the idea of the return as a spontaneous adjunct, but nevertheless form an accepted and expected part of the show. As one audience member, overheard at a Bootleg Beatles concert in Glasgow while the band were off stage, complained: "Come on, we know you're coming back anyway so get on with it!"

\section{Performer/Audience Relationship}

The final point to be made is that the encore ritual draws attention to the performer/audience relationship, and an encore is certainly structured as if performed in direct response to audience demand (a demand which, in turn, is taken to be a response to the performance). The performance of a "crowd-pleasing" song as an encore, to which everyone sings along, acts almost as a reward for the audience who have listened to the rest of their set, which may have contained new and unfamiliar material. As musician Steve Harley explains: "To not do an encore would be churlish. It's like the audience is saying: 'We thanked you, now you thank us'” (Encore!). Another function of the encore is that it also allows the artist to have a short break before reappearing to play, and artists (and audiences) are often more relaxed ("down-geared") during the encore - as they have made it through the bulk of their set (hopefully) successfully. Thus, as photographer Dougie Coulter illustrates, "The best time to take photos is during the encore; that's when they make their best shapes" (Coulter).

Apart from an opportunity to hear their favorite song, it is suggested here that the encore ritual, as posited by Kershaw in his work on the theatrical curtain call, may be the means of the 
audience feeling that it has regained some element of control over the event by calling the artist back (however false this may be in reality). The encore ritual therefore acts as an expression of audience as community. Interestingly, this may be manifested in the physical and vocal actions of the encore ritual itself, as Jackson speculates that a break in events in a ritual "may be reflected in disordered, arrhythmical sounds while a taking up of a rhythmical beat again reasserts human control over events" (296). Cue the arrhythmical stamping and clapping which segues to a unified rhythmical beat once the artist has disappeared from view. The unified behavior that can emerge during the encore (Davidson 219) may aid one of the social functions of music, namely the promotion of group cooperation and cohesion, and hence perpetuation (Dissanayake 48), where the ritualistic nature of the encore joins individuals in a common cause: to ask the artist to reappear and perform once more.

As with Stephen Cottrell's theatre-music taxonomy, in which he quantifies the degree of theatricality within classical music events (172), so there are differences between encores at different types of event; between theatrical spectacles with many "bells and whistles," and those that are plainer and focus more on the artists and their music. It is useful here to compare and contrast the behavior of the audience at King Tut's and at some shows at the Glasgow Royal Concert Hall. While the encore ritual in its fullest form (arrhythmical stamping segueing to rhythmical stamping, etc.) was a common occurrence at the former, it was less so at the latter. Two explanations are possible, the first being that the audience is smaller at King Tut's and closer together, whereas the audience at the Concert Hall are separated into lower and upper sections. The encore ritual relies on the elements being started by an individual or small group of people and then spreading throughout the venue, and perhaps a unanimous audience reaction is 
more difficult to accomplish at the Concert Hall as the audience are more spatially dislocated from each other than at King Tut's.

Secondly, gigs at King Tut's are inherently less choreographed, theatrical, and rehearsed in that the artists do not rely on external props such as dancers or video effects as some do at the Concert Hall. An encore at King Tut's, while pre-planned (as will be discussed later), is not necessarily a given in the same way that encores at theatrical shows like "Here Come the Girls" or The Bootleg Beatles at the Concert Hall are, which must be pre-prepared down to the smallest detail in order to synchronize all the elements therein. It may be that the audiences at such shows understand this and do not need to call the artist back in the same way as they understand that part of the show includes the encore and are complicit in its delivery. Hence the dynamics of a stadium gig such as Take That's 2009 Circus Tour are necessarily different from a small gig in the back of a pub, as the audience implicitly understand that the former is necessarily mechanized while the latter has more scope for spontaneity. In this way, the encore ritual must therefore be enacted fully, perhaps, by audiences at less obviously theatrical shows in order to receive one.

Encore Rituals as Actively Deconstructed, Disturbed, or OMitted

\section{Deconstruction}

The expected and ritualized nature of the encore ritual means that it becomes more interesting when it is actively deconstructed or disturbed. One night at King Tut's, the encore ritual was verbally deconstructed in a humorous manner by solo singer-songwriter Howard Elliot Payne to show what an odd thing it is. The audience responded in an equally humorous way to the way that the artist was acting: he mimed leaving the stage, they shouted "Stamp stamp stamp!" rather 
than actually stamping their feet. While the encore is supposed to be a direct response by the artist to the audience, such fake encores draw attention to the performer/audience relationship again by highlighting the fact that it is, in fact, pre-planned and expected, as if the artist is saying, "You perform your role and I'll perform mine." The deconstruction of the encore ritual is often dealt with in a humorous way by both artist and audience, as the previous example with Sting illustrated. Another example occurred at St George's Bristol in October 2009: Adrian Edmondson and his band, the Bad Shepherds, left the stage after their false ending, and when they reappeared, Edmondson joked: "We're such tarts - we were waiting just behind the door, just waiting to see if you liked us, and we thought, 'Fuck it, it's gonna die down, we better get back on!"” to laughter from the audience.

Artists may alternatively use the encore as an opportunity to play with the conventions, by performing songs at odds with the music that has come before, as illustrated by the following example given by the owner of The Boardwalk in Sheffield:-

I mean, one night after a show here, [Glenn Tilbrook] said his good night, [did] a couple of encores, went into the dressing room in the back and he's having a beer or two, and then he's grabbed his guitar and he just sort of said, 'Bollocks to this, let's do some more!' And he went out, and all the people are down there who were buying CDs and T-shirts, and he came strutting down the venue carrying his guitar, and he stood on the bench seat at the back, and he did about another thirty minutes of ABBA hits. And it was great! (Wilson, emphasis in original).

The Eels often also actively deconstruct the encore ritual, and their final encore shows front man, Mark Everett's “sly convention-splintering at its best." As Nick Hasted writes in his review of their 2005 Royal Albert Hall show, "The lights are up and I'm on my way home before I hear “Mr. E's Beautiful Blues", and return to find the band playing it in their pajamas, to a half-empty 
hall of grinning fans. One of pop's greatest malcontents just couldn't resist the last laugh." Similarly, the Pixies, on occasion, would wait until the audience had left and then play their encore, so that their fans would have to rush back into the room (Aston). A deconstructed encore ritual, then, is an opportunity for artists to play with the conventions of live music, and the fact that artists feel inspired to do so further illustrates how the encore ritual has become a ritualized and expected part of the performance as a whole. One final example is that of New Order, whose Peter Hook compared the encore ritual to "Having sex and then being forced to have another go after you'd had an orgasm" (Simpson). New Order attempted to make the encore more fun by inviting bands like the Happy Mondays on stage with them, or by playing Joy Division songs. Once, apparently, they waited until the houselights were up and then played a twenty minute version of the Velvet Underground's "Sister Ray" for those still in the venue. Now, however, they appear to have "succumbed to the dull curse of trotting on to play the inevitable "Blue Monday"” (ibid).

\section{Disruption}

When a situation occurs to disturb or disrupt the "normal" encore ritual, the consequences can be more dramatic and may lead to confusion. Indeed, as Barron and Inglis state: failure to manage rituals such as the encore "may result in disruptions to the audience's comprehensions of the event" (103). One such example of this occurred at King Tut's where an amp blew and forced the band - Blue October - off stage before the intended encore. This meant that the encore ritual moved to the real end of the set, which caused palpable confusion within the audience as the ritual of calling the artist back did not work. Encore disruption may also be the result of unforeseen circumstances, such as the "Spinal Tap moment" during U2's Popmart tour in Oslo in 
1997, when, as the result of a technical malfunction, the band were trapped in a giant mirrorball lemon during the encore, and were forced to escape through the back (Lester). More dramatically, disruptions may be caused by the ill-health of the artist, such as in 1971 at London's Rainbow Theatre when Frank Zappa was pushed off the stage during the encore by a fan, which later left him wheelchair-bound, or tragically, the collapse and subsequent death of Miriam Makeba at a performance in Italy in 2008 as the crowd shouted for an encore, unaware of what was happening backstage (Rice).

\section{Omission}

Finally, the encore may be deliberately omitted entirely, and some ending rituals actively preclude an encore; for example, The Who smashing up their guitars, or the infamous announcement, "Elvis has now left the building." One audience member at King Tut's spoke of a gig at the Glasgow Barrowlands whereby an audience member had thrown a pint of beer at the band and hit the lead singer on the head (McCluskey). After this, the audience member thought that it seemed as though the band "stopped enjoying the gig" and they retaliated by walking off at the end of their set without playing an encore. This apparently angered the crowd and led to a "damp atmosphere" afterwards which left some audience members angry as they felt the band had not finished the gig properly and that the event was unresolved as a result. As previously noted, the encore draws attention to the artist/audience relationship, where both are expected to conform to their prescribed roles. Thus the encore ritual allows the artist to express dissatisfaction with the behavior of the audience if they do not play by the rules, in that the artist may choose not to perform their pre-planned encore. Shed Seven apparently responded to the lack of audience noise in York during the moment they left the stage by sneaking out of the back 
exit and going home, annoyed that the audience had clearly viewed an encore as a given (Simpson). A similar situation occurred at a Morrissey show at the Palladium in 2006 where the singer left the stage without performing an encore due to the muted audience response (Price). As discussed in more depth later in the article, venue staff may not allow an encore, due to safety fears or time restrictions. Lady GaGa was booed at the V Festival after initially arriving on stage five minutes late and then being forced to cut her set short due to time restrictions ("Lady GaGa booed at V Festival Stafford"). In the case of the Lakota nightclub in Bristol, the security staff move in quickly to disperse the crowd at the end of the night to dissuade both DJ and audience from playing one more tune.

The opposite situation may also occur, however, whereby an artist will return for an encore even though there is a lack of demand from the audience, and a few memorable examples exist of artists returning to play an encore to an underwhelmed or rapidly disappearing audience. One example of such was the Smashing Pumpkins' Glastonbury Festival set in 1997, where an angry crowd, including myself, attempted to dissuade the band from performing an encore after enduring a lackadaisical set of obscure B-sides by the band. In 1976, Tommy Bolin of Deep Purple was allegedly "so smacked out, he couldn't play," so that "when Deep Purple hit the stage, there were 18,000 in the Omni [Atlanta]. When they came out for their encore, there was maybe 300" (MusicGeek). The encore is supposed to say, "We [audience] want more!" and "We [musicians] are pleased to offer it," and so the deliberate boycott of an encore by the audience is therefore a means of expressing their dissatisfaction with - or indifference to - the show they have just experienced. Another reason for omission may be that artists, especially those just starting out, may simply not have any more songs to play, as in the case of The Kissaway Trail at the Liverpool Barfly in 2007, who sheepishly admitted that they had already played their encores 
in the main set (Simpson). For young bands such as this, the encore ritual remains a more genuine interaction between audience and artist. The band does not have the status to perform encores regularly, having not got enough material or an established fan base, hence the request for an encore by the audience at such an occasion is often a more genuine response to a enjoyable set.

Conversely, there are some performances for which an encore seems inappropriate why? Because of a sense of emotional completion. One would not expect an encore after an opera or one of Bach's Passions, for example. An audience member at St George's Bristol related an instance of attending a performance of the St Matthew Passion, where the audience were specifically requested not to applaud at the end but rather to stand up to show their appreciation, adding that he went home "on a high" as the music was allowed to finish in silence (Smith). Some artists, such as the Stone Roses, Manic Street Preachers, or the Wedding Present (or Elvis Presley or The Beatles), choose not to enact the encore ritual at all, sometimes to leave the crowd wanting more, but often to emphasize their difference from their peers and, in the case of the Stone Roses, following in the footsteps of punk and post-punk bands who actively made a point of subverting such rituals. This type of omission appears to be accepted by the audience, however, as the artists are generally consistent in their omission of the ritual. Even so, omission of the encore ritual does depend on a level of insider knowledge within the audience in order to function correctly and so as not to confuse an audience who may have been expecting an encore.

\section{The COMPLicity of the Venue AND/OR PROMOTER}

While the artist and audience must understand the encore ritual, however instinctively (see Frith, 1996: 205), the promoter and/or venue must also be necessarily complicit in order that the 
encore, and therefore the end of the show, ends smoothly. Whether an encore occurs or not may purely be a matter of time, relating to curfews and licensing restrictions, or to how long the artist has been contracted to perform. ${ }^{15}$ For example, at King Tut's, the encore has to be pre-planned between the artist and the venue in order that elements such as background music and house lights do not come back on before the encore begins, and in order to finish the gig before the midnight curfew imposed on the venue. The show times are then derived by working backwards from the curfew, allowing enough time for an encore (Francis). The increasing professionalization and regulation of the live music industry, and the appearance of highly choreographed stage shows such as the aforementioned "Here Come the Girls" concert, mean that the encore has become more and more difficult to $d o$ spontaneously. The increasingly spectacular usage of lighting, computer visuals and pyrotechnics in certain large-scale shows must all be pre-planned, hence the set list, and thus the encore, must be strictly adhered to. The confetti bomb and lasers finale at the end of the Stereophonics gig at Glasgow's SECC in March 2010 would not have been as effective had it happened before their rendition of "Dakota" as the final song of the night, for example.

While promoters and venues must be complicit in the execution of the encore ritual, other promoters and venue staff have even gone so far as to instigate an encore ritual themselves when none appeared to be in the offing. At St George's, venue staff at the back of the auditorium were often the first to start the arrhythmical stamping, and one Glaswegian promoter spoke of one particular occasion where she felt that she had to influence audience behavior:

I remember one time when we did [an artist] at the Grand Ole Opry and it finished and almost nobody clapped! It was really full and it was an amazing show, and we were upstairs on the balcony - there was nobody up on the balcony - and he kind of just got up to walk [off stage], and 
then we started going, 'Woooooh!' Nobody could see us totally hammering on the balcony, howling and stamping our feet, you know, [but] it kind of picked up and it ended up like a standing ovation! (Angus).

Such behavior by venue staff and promoters is generally only effectual in smaller venues, however, where one individual's actions can have a proportionally greater effect on the audience as a whole; in a room of three hundred people, one person will have a greater effect than one person in a room of fifteen thousand people. The above also highlights the need for the backstage personnel to remain covert, as overt instigation of the encore ritual in some circumstances would perhaps be perceived by the audience as inauthentic, or, ironically, pre-planned.

A final example of the complicity of all the participants in the event occurred at "Star Wars: The Concert" in March 2010 at Glasgow's SECC, an event featuring video footage from the six Star Wars films, a full-piece orchestra, and narration by Anthony Daniels ("C3PO"). After the Empire had been vanquished on the big screens and the conductor and narrator had left the stage, video cameras offstage were beamed live to the audience, showing them apparently discussing whether to reappear (cue exaggeratedly shrugging shoulders and looking at watches). The audience's applause and cheers crescendoed when they realized what was being discussed and a man behind me shouted, “C'mon, come back on, that's what it's all about!" Anthony Daniels then reappeared onstage to tease the audience, "You're not quite ready to go home yet! Do you want one more? Shall we return to the Dark Side?" The conductor then returned to his podium to conduct the orchestra, who had remained on stage the whole time this was happening. The orchestra then performed "The Imperial March" as their encore, lit in white light and with no video screens to distract from them. Such an obviously pre-planned encore could only have been possible with the complicity of all the participants, from the conductor and narrator, to the 
cameraman who videoed "discussion" and the technical crew, to the orchestra who remained on stage, and to the audience who remained in their seats.

Conflicts may occur, however, between the performative expectations of the artist and audience, and the legal requirements of the venue, which can impact on the encore ritual. Audiences are often unaware of the many and varied regulations affecting music venues in the UK, and conflicts can occur between what the artist and audience want and what they are legally allowed to do. For example, Queen's infamous Hyde Park show in 1976, which attracted 150200,000 people, was forced to end after eighty minutes as the police threatened to arrest Freddie Mercury if he reappeared on stage, due to the park's curfew. This was following a 1974 show in Stirling where the crowd apparently rioted after Queen refused to play a fourth encore (Duckett). Curfew regulations mean that the promoter and venue must ensure that the show finishes on time, and they may be punished for artists' spontaneity outside of the planned show, as, for example, in 2007, when George Michael's promoters were fined $£ 130,000$ by Wembley because his gig overran by thirteen minutes due to the singer encoring with two extra songs ("Wham singer fined"). The director of the Glasgow International Jazz Festival explained that encores are also pre-planned and rarely spontaneous, and she also highlights the problems that can occur with an improvisatory musical form such as jazz in venues with curfews and employees working overtime:-

I had a show at the [Glasgow] Fruitmarket ... and I had been told the piece was forty-eight minutes long, and it was going to be forty-eight minutes long; that was it, you know, and I said 'It can't be any longer, it just can 't be any longer.' By an hour and ten minutes, we were like that, [opens mouth in a mock scream]. But [the musicians] just go away and play. ... And I've got all 
the crew saying, 'I've got another gig to go and strike; I need to go!' . . Jazz musicians: cannae get them on, cannae get them off, that's what they always say! (Rodger, emphasis in original).

The Dave Matthews Band, who performed at Glasgow's SECC in March 2010, were due to end at $10.15 \mathrm{pm}$ (according to the stewards' safety briefing sheets), but had been given an actual curfew of $11 \mathrm{pm}$ (they finally finished at $10.45 \mathrm{pm}$ ) because the promoter and venue expected the band to play over their set length and had necessarily factored in this perceived spontaneity.

Health and safety regulations are another reason for increased control of artist's sets. The previous example of The Pixies' deconstructed encore, whereby the audience left the venue thinking the gig had finished and then rushed back in for the encore, would perhaps be difficult to imagine happening now. Venues necessarily keep a very tight control on audience entrance and egress, and many follow guidelines set out in the 1999 Event Safety Guide (or "Purple Book"), published by the UK's Health and Safety Executive. As Sam Francis of King Tut's states,

We have our sound curfew in place; we have our health \& safety where we have to do a band risk assessment. Everything we need to do is regulation and everything we do is to comply to that, which makes us a professional venue. There's not one area or field that we don't cover before coming into a live show, so everything needs to be done. So during a gig, those side of stage doors must be closed. That is a regulation, because we're in a built-up area; noise leakage, people around us. Everything we do is very very regulation based (Francis, emphasis in original).

The increasing regulation and professionalization of live music in the UK, and increased development of city centers in areas where live music venues exist, means that noise regulation and curfews are becoming a more common occurrence, hence the tighter controls on the length of artists' sets and the increased necessity of planning an encore. 


\section{CONCLUSION}

While the paper thus far has explored the different types of encore and their functions and meanings, and how the venue and promoter must necessarily understand the process, the question remains: why does the encore ritual persist? Firstly, the encore ritual is ultimately just that: a ritual, a learned and expected part of the event, and, for many contemporary artists and audiences, is part and parcel of the live music event as a whole. Secondly, from over three hundred mini-interviews with audiences, the overwhelming answer to the question, "How do you know how to behave at live music events?" was that people followed what the rest of the audience were doing, whether fellow audience members or family and friends. As young people attend their first music based events and experience and participate in the encore ritual, so the ritual is both learned and thus perpetuated. The third point is that, as Fonarow notes, many young fans and new attendees also form clear expectations about how to behave at gigs from external sources such as reviews, photos and videos (95), hence the importance of external mediators in also teaching audience behavior such as the encore ritual. While fans have always collected set lists after gigs, the increased use of the internet by fans and the media means that artist's set lists are often published online following a live music event. If they are so inclined, a fan is able to find out exactly what the artist will play before they attend the show, including what will be performed for the encore.

To conclude, this paper has explored the hitherto unexplored phenomenon of the encore ritual, illustrating how it has developed from a spontaneous act of crowd enthusiasm to an expected and ritualized part of an artist's performance, but one which now fulfils a variety of useful functions which are markedly different from its original use by audiences. The encore 
ritual marks both the temporality of a music event and also allows the audience to at least feel the semblance of empowerment in an increasingly mechanized, impersonal live music industry. It also enables artists to, albeit somewhat artificially, thank their audiences and finish their sets in a way that is understood, accepted, and expected by their audiences. A final example to illustrate this is Arctic Monkeys, a band I had intended to cite in the previous section about artists who deliberately omit encores. However, having seen them perform at Glasgow's SECC in November 2008, they now appear to also conform to the encore ritual (accompanied by a confetti bomb), which, alongside the other arguments set out in this paper, leads to the conclusion that encores, while disliked in some camps, are here to stay. And yet, as Simpson writes, "The encore ritual is in our hands. Applaud bands back on by all means, but if they come back and trot out an obviously scripted three songs and feign amazement, boo the blighters off." This rallying cry is echoed on the website, Second Encore, whose campaign to encourage a "genuine" second encore attempts to put the power back into the hands of the audience. As the campaign organizers state, "If a small group of you start the calls for a Second Encore others will join in, so take the lead and the rest will follow you!" ("About the Campaign"). In the face of the increasing regulation and mechanization as described above, whether the second encore takes off, or becomes, ironically, as pre-planned and ritualized as the first encore, remains to be seen. 


\section{Acknowledgments}

I would like to acknowledge Simon Frith and Martin Cloonan for their invaluable contributions to this paper. The research is part of a larger project examining the promotion of live music in the UK, and is funded by AHRC research grant F00947/1. 


\section{Notes}

1. For example, Britons spent more on live music concert tickets in 2008 than they did on recorded music (CDs and downloads combined), making the live industry now the largest source of revenue in the British music industries (Prynn; "UK live revenues").

2. For the purposes of my research, live music events also include events at which the music comes from pre-recorded sources such as clubs.

3. A curtain call is the opportunity at the end of a non-musical theatrical production for the audience to call the actors back on to the stage for further applause, but, unlike a musical encore, the actors would not be expected to perform again. As with the encore, often the curtain call will be rehearsed as to who leads the bowing and how many times the cast will bow. Status is also apparent in curtain calls as often the lead actor or actress will be the last person to receive their opportunity to bow. Musical theatre productions often contain a pre-rehearsed repeat of one of the musical numbers in a show.

4. Interestingly, in France and Italy, "Bis!" is used, not "Encore", hence "bisseurs" (Cochrane).

5. This rule was broken, however, in 2007 by tenor Juan Diego Flórez, where "the ovation . . was so overwhelming that [the conductor], was forced by public pressure to allow the tenor . . . to sing the aria again” (Rome).

6. While this paper is mostly focused on popular music events, the ending rituals at classical concerts are also of note, as they share many of the traits and audience behaviors of the true encore ritual: stamping feet, whooping, rhythmic stamping, etc. However, during my research period at classical concerts in Bristol and Glasgow, these behaviors did not usually lead to an actual encore being performed. Perhaps here the audience response was not great enough to 
encourage the artist to perform again, or that protocols for classical music mean that only visiting orchestras are given such an accolade. Only once did I witness an actual encore, at the Glasgow Royal Concert Hall, following a performance of a Tchaikovsky violin concerto by Renaud Capuçon in the first half of the concert. Following extended and enthusiastic applause, he returned to the stage to perform a solo encore before the interval. Capuçon's presence was not required in the second half of the concert and this was the only appropriate time for an encore, highlighting again the differences in encore rituals across music genres.

7. It is possible that the development of the encore ritual in popular music is linked to the rise of the "superstar" or headline artist. An encore disturbs the rhythm of the show, therefore they tend to be limited to headliners, rather than "package tour" artists.

8. However, not all audiences by 1978 were aware of this so-called encore ritual, as the following example illustrates. In Newcastle, Hot Chocolate had left the stage after the "final" song to wait in the wings to be called back. The 2,400 crowd were silent, however, as they "just didn't know how it's done" (Sutcliffe, "Hot Chocolate"). Luckily, after a few minutes of torturous silence in which the band wondered how to return to the stage when the crowd, in fact, had not called them back for more, a few women in the balcony started a "barely audible" chant of "We want more!", after which the band returned to the stage to play another song (ibid).

9. Encore rituals also occur at club type events, although in my experience, the houselights will often be switched on, leaving the audience to dance in the light after calling almost desperately for "One more tune!"

10. This break in events is often used as an opportunity to highlight the availability of merchandise or recorded products for sale, either on-site or in general.

11. Stamping as a means of applause may have evolved from orchestras' method of applause 
for conductors or soloists, namely stamping their feet, as they are unable to use their hands to applaud due to the necessity of holding precious instruments.

12. After the support act's set, the background music would fade up and the side stage lights would be switched on to illuminate the stage; the houselights would stay down, however, to demonstrate to the audience that the show had not yet finished.

13. Another illustration of the difference in status between headline and support artists at King Tut's is that the support artists often have to leave via the front of the stage once they have tidied up and then make their way through to the backstage area through the frontstage stage door (situated next to the bar), unlike the headline artist, who is able to remain unseen before and after the show via the backstage stage door, accessed through the venue car-park and leading directly on to the stage. At other venues, status may be shown by the level of help an artist has to perform their set, such as whether they have a guitar technician to tune guitars for them or deliver them on stage.

14. Similarly, the complicated logistics of a symphony orchestra actually leaving the stage and returning for an encore affects how they may attempt to show spontaneity in other ways, as highlighted previously.

15. Chuck Berry famously would not reappear for an encore unless it was paid for as an extra by the promoter as he saw it as "playing for free" and not part of the original contract (Laurence). 


\section{Works Cited}

“About the Campaign.” About Us. Second Encore. Second Encore, n.d. Web. 31 May 2010

Angus, Isla. Personal interview. 18 Sept. 2009.

Aston, Martin. “More Means Less.” Mojo Blog. Bauer Media, 18 Nov. 2009. Web. 28 May 2010

Barber, Nicholas. “Rock: Listen Carefully: Mansun Only Play Once.” Life and Style. Independent. Independent Print, 16 Mar. 1997. Web. 5 Jan. 2010

Barron, Lee and Inglis, Ian. "(Re)Constructing the Carnival: Continuity and Change in Contemporary British Popular Music.” International Review of the Aesthetics and Sociology of Music 33.1 (2002): 95-112. Print.

Blacking, John. Music, Culture, and Experience: Selected Papers of John Blacking; Edited and with an Introduction by Reginald Byron; with a Foreword by Bruno Nettl. Chicago, Ill./London: U of Chicago P, 1995. Print.

Blom, Eric. "Essay on Listening and Performance." The Musical Companion. Ed. A. L. Bacharach and J. R. Pearce. London: Victor Gollancz, 1934. 649-718. Print.

Botten, Alex. "Review of Embrace/The Delays.” isthismusic.com. Is This Music?, 15 Oct. 2006. Web. 5 Jan. 2010.

Brennan, Matt. "Re: Another question ..." Message to the author. 10 Nov. 2009. E-mail.

Chinen, Nate. "With Jokes and a Kiss, the Police End a Civil Reunion." New York Times. New York Times, 8 Aug. 2008. Web. 5 Jan. 2010.

Cloonan, Martin. "Re: Encore rituals.” Message to the author. 5 Nov. 2009. E-mail. 
Cochrane, Lalage. "Encore.” The Oxford Companion to Music. Ed. Alison Latham. Oxford Music Online. Web. 28 Oct. 2009.

Cottrell, Stephen. Professional Music-making in London: Ethnography and Experience. Aldershot, Hants., Eng.: Ashgate Publishing, 2004. Print.

Coulter, Dougie. Personal interview. 6 Oct. 2009.

Davidson, Jane. “The Social in Music Performance.” The Social Psychology of Music. Ed. David J. Hargreaves and Adrian North. Oxford: Oxford UP, 1997. 209-226. Print.

Dissanayake, Ellen. "Ritual and Ritualisation: Music Means of Conveying and Shaping Emotion in Humans and Other Animals." Music and Manipulation: On the Social Uses and Social Control of Music. Ed. Steven Brown and Ulrik Volgsten. New York/Oxford: Berghahn Books, 2006. 31-57. Print.

Duckett, Simon. "Queen Live in the 1970s." Record Collector, n.ed. Diamond Publishing, June 1989. Print.

“Elvis Presley 1953-55.” Biography. elvispresleymusic.com.au. EP Music, n.d. Web. 6 Nov. 2009.

Encore! Narr. Guy Garvey. Prod. Ian Bent. BBC Radio 4. 16 Oct. 2009. Radio.

Fairley, Jan. “Analysing Performance: Narrative and Ideology in Concerts by ¡Karaxú!” Popular Music 8.1 (1989): 1-30. Print.

Fonarow, Wendy. Empire of Dirt: The Aesthetics and Rituals of British Indie Music. Middletown, Conn.: Wesleyan UP, 2006. Print. 
Francis, Sam. Personal interview. 9 June 2009.

Frith, Simon. Performing Rites: On the Value of Popular Music. Oxford: Oxford UP, 1996. Print.

---. "Re: Encore rituals." Message to the author. 5 Nov. 2009. E-mail.

Goffman, Erving. “The Lecture.” Forms of Talk. Oxford: Blackwell, 1981. 160-196. Print.

Hasted, Nick. "Eels, Royal Albert Hall, London.” Arts and Entertainment. Independent. Independent Print, 14 Oct. 2007. Web. 28 May 2010

Health and Safety Executive. The Event Safety Guide: A Guide to Health, Safety and Welfare at Music and Similar Events. 2nd Revised Edition. Sudbury, Eng.: HSE Books, 1999. Print.

Jackson, Anthony. “Sound and Ritual." Man 3.2 (1968): 293-299. Print.

Kershaw, Baz. "Oh for Unruly Audiences! Patterns of Participation in Twentieth-Century Theatre." Modern Drama 44.2 (2001): 133-154. Print.

“Killers, Coldplay, U2, Take That Team-up for Post BRITs Gig." NME.com. IPC Media, 19 Feb. 2009. Web. 31 May 2010.

"Lady GaGa Booed at V Festival Stafford.” NME.com. IPC Media, 22 Aug. 2009. Web. 2 June 2010.

Laurence, Charles. “Chuck Berry’s Rock'n'Roll Past Makes the Big Screen.” First Post. First Post News Group, 9 Dec. 2008. Web. 9 Dec. 2009 
Lester, Paul. “U2's Latest Tour - Ludicrous, Expensive and a Bit Hypocritical.” Guardian. Guardian News and Media, 30 July 2009. Web. 2 June 2010

Lydon, Michael. "Monterey Pops! An International Pop Festival.” (Unpublished). Newsweek, 20 June 1967. Rocks Back Pages. Web. 28 Oct. 2009.

McCluskey, David. Personal interview. 4 June 2009.

Merriam, Alan. The Anthropology of Music. Evanston: Northwestern UP, 1964. Print.

MusicGeek. "Worst Concerts Ever.” Anniston Star Blog. Consolidated Publishing, 5 Sept. 2007. Web. 28 May 2010.

Nettl, Bruno. Study of Ethnomusicology: Twenty-nine Issues and Concepts. Urbana: Illinois U.P, 1983. Print.

Peterson, Richard A. "Why 1955? Explaining the Advent of Rock Music." Popular Music 9 (1990): 97-116. Print.

Pitts, Stephanie. Valuing Music Participation. Aldershot, Hants., Eng.: Ashgate Publishing, 2005. Print.

Price, Simon. "Breast in Peace, The Darkness." Independent. Independent Print, 31 Dec. 2006. Web. 31 May 2010.

Prynn, Jonathan. "Festival Explosion turns Live Music into £1.9bn Big Business.” Evening Standard. ES London, 10 Sept. 2008. Web. 5 Jan. 2010.

Revermann, Martin. "The Semiotics of Curtain Calls.” Semiotica 168.1 (2008): 191-202. Print. 
Rice, Xan. “"Mama Africa” Makeba Dies at 76.” Guardian. Guardian News and Media, 11. Nov. 2008. Web. 13 July 2010

Rodger, Jill. Personal interview. 30 Oct. 2009.

Rome, Richard Owen. "Pavarotti's Heir Breaks Rules with Encore on the High Cs." Times. Times Newspapers, 22 Feb. 2007. Web. 5 Jan. 2010

Scholes, Percy, et al. “Applause.” The Oxford Companion to Music. Ed. Alison Latham. Oxford Music Online. Web. 16 Aug. 2010.

Simpson, Dave. "Encore? Encore? Enough of this Crushingly Predictable Gig Ritual." Music Blog. Guardian. Guardian News and Media, 17 May 2007. Web. 5 Jan. 2010.

Small, Christopher. Musicking: The Meanings of Performing and Listening. Middletown, Conn.: Wesleyan UP, 1998. Print.

Smith, Alan. Personal interview. 2 Oct. 2009.

Sutcliffe, Phil. "Hot Chocolate: City Hall, Newcastle." Sounds, 1 Apr. 1978. Rocks Back Pages. Web. 31 May 2010.

---. "David Bowie: City Hall, Newcastle.” Sounds, 24 June 1978. Rocks Back Pages. Web. 28 Oct. 2009.

Turino, Thomas. Music as Social Life: The Politics of Participation. Chicago: U of Chicago P, 2008. Print.

"UK Live Revenues Surpass Record Sales.” Music Week. UBM Information, 17 Mar. 2009. Web. 
5 Jan. 2010.

Walls, Peter. "Encore.” Grove Music Online. Oxford Music Online. Web. 16 Aug. 2010

“Wham Singer Fined £130k for Wembley Encore.” Music Week. UBM Information, 12 July 2007. Web. 5 Jan. 2010

Wilson, Chris. Personal interview. 21 Aug. 2008. 